\title{
A Qualitative Systematic Review of the Role of N-Methyl-D- Aspartate Receptor Antagonists in Preventive Analgesia
}

\author{
Colin J. L. McCartney, FRCA*, Avinash Sinha, FRCA*, and Joel Katz, PhD $\$ \$$ \\ *Department of Anesthesia and Pain Management, Toronto Western Hospital and University of Toronto; tDepartment of \\ Anesthesia, University of Toronto; $₫$ Department of Anesthesia and Pain Management, Toronto General Hospital and \\ Mount Sinai Hospital; and §Department of Psychology and School of Kinesiology and Health Science, York University, \\ Toronto, Ontario, Canada
}

\begin{abstract}
We evaluated in a qualitative systematic review the effect of $N$-methyl-D-aspartate (NMDA) receptor antagonists on reducing postoperative pain and analgesic consumption beyond the clinical duration of action of the target drug (preventive analgesia). Randomized trials examining the use of an NMDA antagonist in the perioperative period were sought by using a MEDLINE (1966-2003) and EMBASE (1985-2003) search. Reference sections of relevant articles were reviewed, and additional articles were obtained if they evaluated postoperative analgesia after the administration of NMDA antagonists. The primary outcome was a reduction in pain, analgesic consumption, or both in a time period
\end{abstract}

beyond five half-lives of the drug under examination. Secondary outcomes included time to first analgesic request and adverse effects. Forty articles met the inclusion criteria (24 ketamine, 12 dextromethorphan, and 4 magnesium). The evidence in favor of preventive analgesia was strongest in the case of dextromethorphan and ketamine, with $67 \%$ and $58 \%$, respectively, of studies demonstrating a reduction in pain, analgesic consumption, or both beyond the clinical duration of action of the drug concerned. None of the four studies examining magnesium demonstrated preventive analgesia.
$\mathbf{T}$ he $N$-methyl-D-aspartate (NMDA) receptor is an excitatory amino acid receptor that has been implicated in the modulation of prolonged pain states in animal models (1). NMDA antagonists, such as ketamine and dextromethorphan, have been shown to be useful in the reduction of acute postoperative pain, analgesic consumption, or both when they are added to more conventional means of providing analgesia, such as opioids and nonsteroidal antiinflammatory drugs, in the perioperative period $(1,2)$.

Intraoperative and postoperative noxious inputs may cause central sensitization, but analgesic interventions given before the noxious stimulus may attenuate or block sensitization and, hence, reduce acute pain (3). The concept of preemptive analgesia was

Joel Katz is supported by a Canada Research Chair in Health Psychology at York University, Toronto, ON, Canada. initially put forward by Crile (4) and then by Wall (3), who suggested that the administration of opioids or local anesthetics before surgery might reduce the C-fiber-induced injury barrage associated with incision and, thereby, the intensity of postoperative pain. This first definition of preemptive analgesia did not include the imperative to compare a preoperative intervention with a postoperative intervention. This requirement, adopted shortly thereafter (5), imposed a constraint that limited the demonstration of preemptive analgesia to experimental designs with less potential for clinically significant effects. The evidence in support of preemptive analgesia by this strictest of definitions has been equivocal, and a recent systematic review of the literature examining the role of preemptive analgesia and the role of timing of analgesia demonstrated no overall benefit of this concept (6).

However, since the introduction of the term preemptive analgesia into the pain and anesthesia literature, the concept has evolved. The previously held belief that it was the surgical incision that triggered central sensitization has been expanded to include the sensitizing effects of preoperative noxious inputs and pain, as well as other noxious intraoperative and postoperative stimuli. This would suggest that the previous definition of preemptive analgesia is too restrictive (7), 
because an analgesic intervention given after surgical incision (e.g., during or after surgery) may also reduce central sensitization and thus decrease postoperative pain intensity. We can evaluate this possibility only by adding a control group that does not receive the analgesic intervention, a group that receives the intervention before and after surgery, or both groups. Unfortunately, many negative studies examining for a preemptive analgesic effect do not include appropriate control groups and hence may be missing an important effect.

The term preventive analgesia (8) was introduced to emphasize the fact that central sensitization is induced by noxious preoperative and postoperative inputs and has been used to describe a reduction in postoperative pain intensity, analgesic use, or both beyond the clinical duration of action of the target preventive drug $(9,10)$. Thus, in the absence of a postincisional intervention, the finding that pain or analgesic consumption is reduced beyond the pharmacological duration of action relative to an untreated or placebo control condition is evidence of a preventive analgesic effect. Thus, the aim of preventive analgesia is to reduce central sensitization that arises from noxious inputs across the entire perioperative period and not just from those brought about by incision. The concept of preventive analgesia, therefore, has greater clinical relevance than does preemptive analgesia $(8,10)$.

Although many drugs have demonstrated evidence of preventive analgesic benefit (9), treatments that are likely to prevent the development of central excitability may have the greatest benefit. Because antagonists at the NMDA receptor have potential for attenuating central sensitization, we conducted a systematic review of the literature to determine the extent to which NMDA antagonists have yielded preventive analgesic effects when given during the perioperative period.

\section{Methods}

We systematically conducted a search of the MEDLINE and EMBASE databases from 1966 to April 2003 (MEDLINE) and from 1985 to April 2003 (EMBASE) by using the following key words and limiting the search strategy to English language reports in humans: "pre-emptive analgesia" or "preemptive analgesia," "pre-operative," "preoperative," "post-operative," "postoperative," "preincision," "preincision," "post-incision," "postincision," and "timing." These key words were then crossreferenced with the following: NMDA, ketamine, memantine, amantadine, dextromethorphan, magnesium, and methadone. Reference sections of relevant articles were reviewed, and additional articles were obtained if they evaluated postoperative analgesia after the administration of NMDA antagonists. Authors were not contacted for original data.
The criteria for assessing the quality of reports as described by Jadad et al. (11) were used, and the quality score was recorded. Studies without randomization and blinding were excluded. Therefore, the minimum score of an included study was 2 , and the maximum score was 5 . In addition to a randomized protocol and double-blinded assessment of pain and analgesic use, studies also had to include a report of pain or hyperalgesia by using a reliable and valid measure (e.g., visual analog scale, numeric rating scale, verbal descriptor scale, quantitative sensory testing, or pressure algometry), a report of analgesic consumption, and, for studies that assessed the effect of timing according to the definition of preventive analgesia, consumption of analgesics reported at a point in time that exceeded the duration of action of the target drug whose effect on postoperative pain was being examined. For the purposes of this review, a point in time equivalent to five half-lives of the drug under examination was taken as exceeding the clinical duration of action of the drug. This criterion, although stringent, was chosen to ensure that observed effects were not simply direct analgesic effects of residual drug. The stated half-life of each drug was determined and found to be $3 \mathrm{~h}$ for ketamine (12), 2-4 $\mathrm{h}$ for dextromethorphan (13), $20 \mathrm{~h}$ for methadone (14), and $5 \mathrm{~h}$ for ionized magnesium (15). The final criterion was the absence of methodological problems that render results ambiguous and make interpretation difficult.

A preventive analgesic effect was confirmed if pain, analgesic consumption, or both were significantly reduced $(P<0.05)$ five half-lives beyond the administration of the NMDA antagonist under examination or

Table 1. Excluded Studies by Criteria

\begin{tabular}{lcc}
\hline \multicolumn{1}{c}{ Criteria not fulfilled } & $\begin{array}{c}\text { No. } \\
\text { Studies }\end{array}$ & References \\
\hline Inadequate blinding & 6 & $16-21$ \\
No control group & 11 & $22-32$ \\
Not randomized & 9 & $33-41$ \\
No preventive analysis possible & 53 & $42-94$ \\
$\quad$ beyond five half-lives & & \\
Inadequate pain measure & 9 & $95-103$ \\
Case report & 2 & 104,105 \\
Not perioperative & 4 & $106-109$ \\
Negative preemptive study with no & 2 & 110,111 \\
$\quad$ placebo control & & \\
\hline
\end{tabular}

Table 2. Study Quality Score by Drug and Positive or Negative Outcome

\begin{tabular}{lcrc}
\hline \multicolumn{1}{c}{ Drug } & $\begin{array}{c}\text { Positive } \text { studies }^{a} \\
\text { Ketamine }\end{array}$ & $\begin{array}{c}\text { Negative } \\
\text { studies }^{a}\end{array}$ & $\begin{array}{c}P \\
\text { value }\end{array}$ \\
Dextromethorphan & $3.5(2-5)$ & $4(2-4)$ & 0.7 \\
Magnesium & $3.5(2-5)$ & $4.5(4-5)$ & 0.8 \\
\hline
\end{tabular}

$\mathrm{NA}=$ not applicable.

${ }^{a}$ Median (range). 
if the first analgesic request occurred beyond five halflives of the drug concerned, and if it was significantly longer than that in the control group $(P<0.05)$. Positive preemptive analgesic studies in which pain, analgesic consumption, or both were reduced in a preincisional group in relation to a postincisional group and placebo control were also included. However, negative preemptive studies that did not include a placebo control group were excluded, because it could not be determined whether a preventive analgesic effect had occurred (both preincisional and postincisional groups may have received analgesic benefit, and these groups could not be contrasted with a placebo control group).

Differences in study quality (11) were analyzed with the Mann-Whitney $U$-test by using SPSS for Windows Version 9.0 (SPSS Inc., Chicago, IL). $P<0.05$ was considered significant.

\section{Results}

The MEDLINE and EMBASE searches identified 136 articles that examined the use of an NMDA antagonist for perioperative pain management. Forty studies fulfilled the inclusion criteria outlined previously. Ninety-six studies were excluded. The most frequent reason for exclusion ( $n=53$ studies) was the failure to design the study to test for a preventive analgesic effect (i.e., absence of pain and/or analgesic data beyond five half-lives of the drug). Two studies were excluded because they were negative preemptive studies with no placebo control group. Two were case reports, 4 did not examine a surgical population, and 35 were excluded because of methodological flaws. Table 1 [[16-20,21-25,26-36,37-50,51-61,62-75,76$86,87-100,101-111]$ llists the studies that were excluded from the review and shows which of the inclusion criteria were not met.

Of the included studies, 24 examined the use of ketamine (112-135), 12 examined dextromethorphan (136-147), and 4 examined magnesium (148-151). A total of 2034 patients were studied, and the number of patients in the studies ranged from a minimum of 18 in a study using a crossover design (133) to a maximum of 121 patients in the largest randomized controlled trial (112). Study quality across the positive and negative studies for each drug is presented in Table 2. There were no significant differences in study quality between studies that found positive or negative outcomes for each drug.

Quantitative analysis of the degree of analgesic benefit was not performed because of the variability of consistency of reporting of numerical pain and analgesic consumption data. Thirty-six (90\%) of 40 studies presented data in tables together with significance levels ( $P$ values) or in other formats that allowed for assessment of the degree of benefit but did not allow for quantitative analysis. Instead, data have been presented in table format for each drug, as performed for other recent qualitative systematic reviews (152).

Twenty-four studies examined ketamine (Table 3), and $14(58 \%)$ demonstrated a positive preemptive or preventive analgesic effect. Three studies used a preemptive design $(113,115,134)$, and 21 studies used a preventive design. Of the 10 negative studies, $6 \mathrm{did}$ not demonstrate any direct analgesic effect of the intervention. Patients enrolled in these studies underwent a variety of surgical procedures, including ambulatory and major inpatient surgery, and doses ranged from 0.15 to $1 \mathrm{mg} / \mathrm{kg}$. There was no obvious effect of surgical type on the success of the preventive intervention, and success did not depend on the dose administered.

Ketamine was administered IV in nine positive studies and seven negative studies, epidurally or intrathecally in four positive and three negative studies, and subcutaneously in one positive study. Most studies (both positive and negative) coadministered opioids with ketamine. However, in two positive studies, an analgesic benefit was demonstrated with the NMDA antagonist alone (without coadministered opioid) $(116,121)$.

Twenty of 24 studies documented evaluation of adverse effects, including psychomimetic effects. Twelve studies documented no adverse effects. Seven studies documented adverse effects but found no difference between treatment and control groups. One study documented psychomimetic effects related to epidural ketamine $20 \mathrm{mg}$ (120).

Twelve studies examined the use of dextromethorphan (Table 4), and eight (67\%) demonstrated evidence of a preemptive or preventive analgesic effect. Three studies used a preemptive $(136,138,145)$ and nine studies used a preventive design. Of the four negative studies, two $(141,142)$ did not demonstrate any direct effect of the analgesic intervention.

Both positive and negative studies used a variety of major and minor surgical procedures, and the success of the preventive intervention did not appear to be associated with the type of surgery. Dosages varied from $0.5 \mathrm{mg} / \mathrm{kg}$ to $150 \mathrm{mg}$ and did not appear to be associated with the success of the intervention. Two of the studies in the negative group $(141,142)$ used a smaller dose by the oral route that was not associated with a direct analgesic effect. Positive studies used both oral (four studies) and IV or IM routes, whereas all four negative studies used the oral route.

All but one study coadministered an opioid for analgesia, and therefore preventive analgesia may have been related to a reduction in opioid tolerance in many studies. One study (147) that did not use a coadministered opioid demonstrated a direct analgesic effect of the dextromethorphan itself. 
Table 3. Studies Examining Ketamine That Met Inclusion Criteria

\begin{tabular}{|c|c|c|c|c|}
\hline Study & $\begin{array}{l}\text { Quality score } \\
\qquad(0-5)\end{array}$ & No. Patients/procedure & $\begin{array}{l}\text { Co-admin } \\
\text { opioid }\end{array}$ & $\begin{array}{c}\text { Groups } \\
\text { (treatment combination) }\end{array}$ \\
\hline Aida (112) & $-\ldots$ & $121 /$ distal or total gastrectomy & Yes & $\begin{array}{l}\text { Pre-med hydroxyzine } 1 \mathrm{mg} / \mathrm{kg}+\text { atropine } 0.01 \mathrm{mg} / \mathrm{kg} \\
\text { GA plus: } \\
\text { G1: MORep- } \\
\text { G2: KET IV } \\
\text { G3: COMB } \\
\text { G4: control }\end{array}$ \\
\hline Choe (113) & $\cdots$ & $60 /$ subtotal gastrectomy & Yes & $\begin{array}{l}\text { GA plus epidural; } \\
\text { G1: Morph + KET pre-ind } \\
\text { G2: Morph + KET intra-op }\end{array}$ \\
\hline Menigaux (123) & 4 & 45/arthroscopic ACL repair & Yes & $\begin{array}{l}\text { Pre-med oral hydroxyzine } 100 \mathrm{mg} \\
\text { 1-2 h pre-op } \\
\text { GA plus: } \\
\text { G1: pre-inc; } \\
\text { KET + saline } \\
\text { G2: Post-inc; } \\
\text { Saline + KET } \\
\text { Control group: saline + saline }\end{array}$ \\
\hline Tverskoy (133) & 3 & 18/unilateral \& bilateral herniorrhaphy & Yes & $\begin{array}{l}\text { GA plus: bilateral repair-Bupiv + KET \& Bupiv } \\
\text { Unilateral repair-Bupiv + KET or Bupiv }\end{array}$ \\
\hline Fu (115) & 3 & 40/abdominal surgery & Yes & $\begin{array}{l}\text { Midazolam } 0.05 \mathrm{mg} / \mathrm{kg} \text { at induction } \\
\text { GA plus KET; Pre-inc bolus + infusion } \\
\text { Post-inc bolus only }\end{array}$ \\
\hline Wong (134) & 2 & $45 /$ total knee replacement & Yes & $\begin{array}{l}\text { Pre-med diazepam } 5 \mathrm{mg} \text { IV } \\
\text { Group G: GA + post-inc intervention } \\
\text { Group EB: epidural + pre-inc intervention } \\
\text { Group EA: epidural + post-inc intervention }\end{array}$ \\
\hline Himmelseher (116) & 5 & 37/ unilateral total knee arthroplasty & No & $\begin{array}{l}\text { Midazolam } 3.75-7.5 \mathrm{mg} \text { oral pre-med } 1 \mathrm{~h} \text { pre-op } \\
\text { G1: epidural Ropiv + S(+)-KET \& sedation } \\
\text { G2: epidural Ropiv + saline \& sedation }\end{array}$ \\
\hline Menigaux (124) & 5 & 50/arthroscopic meniscal surgery & Yes & $\begin{array}{l}\text { Hydroxyzine } 100 \mathrm{mg} \text { oral pre-med, } 1-2 \mathrm{~h} \text { pre-op } \\
\text { GA TCI propofol plus; } \\
\text { G1: KET } \\
\text { G2: control }\end{array}$ \\
\hline Mortero (125) & 3 & $39 /$ day surgery & Yes & $\begin{array}{l}\text { Midazolam 1-3 mg IV pre-med + fentanyl } 50 \mu \mathrm{g} \mathrm{IV} \\
\text { Infusion of study drug during surgery: } \\
\text { G1: propofol alone } \\
\text { G2: propofol + KET } 0.98 \mathrm{mg} / \mathrm{mL}\end{array}$ \\
\hline Stubhaug (129) & 5 & 20/nephrectomy & Yes & $\begin{array}{l}\text { GA + bolus study drug followed by } 48-\mathrm{h} \text { infusion } \\
\text { G1: KET: } 0.5 \mathrm{mg} / \mathrm{kg} \text { bolus }+2 \mathrm{mg} \cdot \mathrm{kg}^{-1} \cdot \mathrm{min}^{-1} \text { for } 24 \mathrm{~h} \text { then } \\
1 \mathrm{mg} \cdot \mathrm{kg}^{-1} \cdot \mathrm{min}^{-1} \text { up to } 48 \mathrm{~h} \\
\text { G2: placebo: saline bolus }+ \text { infusion only }\end{array}$ \\
\hline
\end{tabular}


Table 3. (Continued)

\begin{tabular}{|c|c|c|c|}
\hline Route/dose/timing & Systemic analgesic & $\begin{array}{c}\text { Direct } \\
\text { analgesic effect }\end{array}$ & Preventive/preemptive analysis ${ }^{a}$ \\
\hline $\begin{array}{l}\text { IV KET bolus } 1 \mathrm{mg} / \mathrm{kg} 10 \mathrm{~min} \text { pre-inc }+ \text { infusion } \\
\text { at } 0.5 \mathrm{mg} \cdot \mathrm{kg}^{-1} \cdot \mathrm{h}^{-1} \text { until skin closure } \\
\text { Epidural morphine bolus } 0.06 \mathrm{mg} / \mathrm{kg} 40 \text { min pre- } \\
\text { inc }+ \text { infusion at } 0.02 \mathrm{mg} \cdot \mathrm{kg}^{-1} \cdot \mathrm{h}^{-1} \text { until skin } \\
\text { closure. } \\
\text { MORep: MORep only } \\
\text { KET IV: KET IV only } \\
\text { COMB: both MORep \& KET IV } \\
\text { Control: saline epidural and IV bolus }+ \text { infusion }\end{array}$ & $\begin{array}{l}\text { Naloxone } 0.008 \mathrm{mg} / \mathrm{kg} \mathrm{IV} \text { at end of surgery } \\
\text { Post-op PCA morphine }\end{array}$ & Yes & $\begin{array}{l}\text { Preventive effect; lowest VAS \& Analg. Req. } \\
\text { over } 48 \mathrm{~h} \text { with combination of MORep \& } \\
\text { IV KET } \\
\text { COMB }<\text { KET IV }<\text { MORep < control } \\
\text { Significant difference in VAS \& Analg. Req. } \\
\text { over } 48 \mathrm{~h}\end{array}$ \\
\hline $\begin{array}{l}\text { Epidural injection } \\
\text { G1: KET } 60 \mathrm{mg}+\text { morphine } 2 \mathrm{mg} \text { pre-ind of GA } \\
\text { \& } 8 \mathrm{~mL} \text { of saline intra-op after removal of } \\
\text { specimen } \\
\text { G2: } 8 \mathrm{~mL} \text { of saline pre-ind of GA \& KET } 60 \mathrm{mg}+ \\
\text { morphine } 2 \mathrm{mg} \text { intra-op after removal of } \\
\text { specimen }\end{array}$ & $\begin{array}{l}\text { Post-op epidural } \\
\text { Bupiv } 0.25 \% 8 \mathrm{~mL}+2 \mathrm{mg} \text { morphine }\end{array}$ & Yes & $\begin{array}{l}\text { Preemptive effect; more supplemental } \\
\text { analgesia required in G2 versus G1; } \\
\text { duration of analgesia } G 1>G 2\end{array}$ \\
\hline $\begin{array}{l}\text { IV bolus injections; } 10 \mathrm{~min} \text { after induction, before } \\
\text { inflation of tourniquet, and at end of surgery } \\
\text { Pre-inc: KET } 0.15 \mathrm{mg} / \mathrm{kg} \text { at induction \& saline at } \\
\text { end of surgery } \\
\text { Post-inc: saline at induction \& KET } 0.15 \mathrm{mg} / \mathrm{kg} \text { at } \\
\text { end of surgery } \\
\text { Control: saline both at induction and end of } \\
\text { surgery }\end{array}$ & $\begin{array}{l}\text { Sufentanil } 0.2 \mathrm{~g} / \mathrm{kg}+0.25 \mathrm{mg} \cdot \mathrm{kg}^{-1} \cdot \mathrm{min}^{-1} \\
\text { post-op PCA morphine }\end{array}$ & Yes & $\begin{array}{l}\text { Preventive effect; significant difference in } \\
\text { Analg. Req. over } 24 \& 48 \mathrm{~h} \\
\text { Control }>\text { Pre-inc }=\text { Post-inc; no significant } \\
\text { difference in VAS }\end{array}$ \\
\hline $\begin{array}{l}10 \mathrm{~mL} \text { wound infiltration at end of surgery } \\
\text { Bilateral-one side Bupiv } 0.5 \%+\mathrm{KET} 0.3 \% \text { \& } \\
\text { other side } \\
\text { Bupiv alone } \\
\text { Unilateral-cases randomized to receive either } \\
\text { Bupiv } 0.5 \%+\text { KET } 0.3 \% \text { or Bupiv } 0.5 \% \text { alone }\end{array}$ & $\begin{array}{l}\text { Post-op dipyrone } 0.5 \mathrm{~g} \text { PO meperidine } 25 \mathrm{mg} \\
\text { IM }\end{array}$ & Yes & $\begin{array}{l}\text { Peripheral preventive effect; in patients with } \\
\text { bilateral repair pain threshold level } \\
\text { increased with addition of KET to Bupiv } \\
\text { compared with contralateral side }\end{array}$ \\
\hline $\begin{array}{l}\text { IV KET bolus } 0.5 \mathrm{mg} / \mathrm{kg}+\text { infusion } \\
10 \mathrm{mg} \cdot \mathrm{kg}^{-1} \cdot \mathrm{min}^{-1} \\
\text { Pre-inc: bolus at induction }+ \text { infusion started \& } \\
\text { discontinued at wound closure } \\
\text { Post-inc: bolus at wound closure only }\end{array}$ & No intra-op opioids; post-op PCA morphine & Yes & $\begin{array}{l}\text { Preemptive effect; significant difference in } \\
\text { Analg. Req. over } 48 \mathrm{~h} \text {; } \\
\text { Post-inc > Pre-inc; no significant difference } \\
\text { in VAS }\end{array}$ \\
\hline $\begin{array}{l}\text { Group G: GA plus pre-inc epidural saline } 15 \mathrm{~mL} \text {, } \\
\text { intra-op epidural saline } 10 \mathrm{~mL}+\text { morphine } \\
1.5 \mathrm{mg}+\text { KET } 20 \mathrm{mg} 30 \mathrm{~min} \text { after skin incision } \\
\text { Group EB: epidural lidocaine } 2 \% 15 \mathrm{~mL} \& \\
\text { morphine } 1.5 \mathrm{mg}+\text { KET } 20 \mathrm{mg} 30 \mathrm{~min} \text { pre-inc } \\
\text { Group EA: pre-inc epidural lidocaine } 2 \% 15 \mathrm{~mL} \& \\
\text { morphine } 1.5 \mathrm{mg}+\text { KET } 20 \mathrm{mg} 30 \mathrm{~min} \text { post-inc }\end{array}$ & $\begin{array}{l}\text { Post-op PCA morphine \& } 10 \mathrm{~mL} \text { epidural } \\
\text { bolus of lidocaine } 0.32 \%+\text { morphine } 1 \mathrm{mg} \\
\quad+\text { KET } 10 \mathrm{mg} \text { every } 12 \mathrm{~h} \text { for } 72 \mathrm{~h}\end{array}$ & Yes & $\begin{array}{l}\text { Preemptive effect } \\
\text { Group EB: epidural + pre-inc } \\
\text { intervention--least Analg. Req. and } \\
\text { lowest VAS at } 12 \& 72 \mathrm{~h} \\
\text { Group EB }<\text { Group EA }<\text { Group G }\end{array}$ \\
\hline $\begin{array}{l}\text { Intra-op sedation with IV propofol or midazolam } \\
\text { in all cases } \\
\text { Bolus Ropiv } 45 \mathrm{~min} \text { pre-op } \\
\text { Intervention } 10 \mathrm{~min} \text { pre-inc } \\
\text { Epidural block dermatome }>\mathrm{T} 12 \\
\text { G1: Ropiv } 1 \% 10-20 \mathrm{~mL} \text { epidural bolus }+\mathrm{S}(+)- \\
\text { KET } 0.25 \mathrm{mg} / \mathrm{kg} \\
\text { G2: Ropiv } 1 \% 10-20 \mathrm{~mL} \text { epidural bolus }+ \text { saline }\end{array}$ & $\begin{array}{l}\text { Post-op PCEA Ropiv rescue analgesia; } \\
\text { diclofenac } 50-100 \mathrm{mg} \text { or acetaminophen } \\
0.5-1 \mathrm{~g} \text { PR followed by metamizol } 1-2 \mathrm{~g} \\
\text { IV persistent pain; Ropiv epidural bolus or } \\
\text { infusion } \\
\text { Piritramide } 1.5-7.5 \mathrm{mg} \mathrm{SC} / \mathrm{IV} \text { or IV PCA }\end{array}$ & Yes & $\begin{array}{l}\text { Preventive effect; Analg, Req. (PCEA Ropiv) } \\
\quad \text { \& VAS at } 24 \text { \& } 48 \mathrm{~h} \mathrm{G}>\mathrm{G} 1 \\
\text { Time to first analgesia, sensory block similar } \\
\text { Analg. Req. NSAIDs \& opioids } \\
\text { G1 = G2 }\end{array}$ \\
\hline $\begin{array}{l}\text { GA TCI propofol intervention; } \mathrm{V} \text { bolus just after } \\
\text { induction } \\
\text { G1: KET } 0.15 \mathrm{mg} / \mathrm{kg} \text { KET diluted in } 10 \mathrm{~mL} \text { of } \\
\text { saline } \\
\text { G2: control; } 10 \mathrm{~mL} \text { saline }\end{array}$ & $\begin{array}{l}\text { Alfentanil } 20 \mu \mathrm{g} / \mathrm{kg} \text { IA Bupiv } 0.5 \%+ \\
\text { morphine } 5 \mathrm{mg} \text { at end of arthroscopy } \\
\text { Post-op morphine } 3 \mathrm{mg} \text { every } 5 \mathrm{~min} \text { PRN } \\
\text { All patients received naproxen } 550 \mathrm{mg} \text { on } \\
\text { discharge; naproxen } 550 \mathrm{mg}+ \\
\text { acetaninophen } 800 \mathrm{mg} / \\
\text { dextropropoxyphene } 60 \mathrm{mg} \text { every } 6 \mathrm{~h} \text { PRN }\end{array}$ & Yes & $\begin{array}{l}\text { Preventive effect; Analg. Req. \& VAS } \\
\text { throughout study } \\
\mathrm{KET}<\text { control }\end{array}$ \\
\hline $\begin{array}{l}\text { Infusion of study drug pre-op } \\
0.3-0.5 \mathrm{~mL} \cdot \mathrm{kg}^{-1} \cdot \mathrm{min}^{-1} \\
\text { Fentanyl } 50 \mu \mathrm{g} \text { increments for pain }\end{array}$ & $\begin{array}{l}\text { In PACU: morphine } 2 \mathrm{mg} \text { IV for VAS > } \\
30 \mathrm{~mm} \\
\text { Hydrocodone PO for pain after discharge }\end{array}$ & Yes & $\begin{array}{l}\text { Preventive effect; pain and analgesic } \\
\text { consumption significantly reduced on } \\
\text { Day } 3 \text { post-op }\end{array}$ \\
\hline $\begin{array}{l}\text { Post-ind of GA and pre-inc intervention } \\
\text { KET } 0.5 \mathrm{mg} / \mathrm{kg} \text { IV bolus, then } \\
2 \mathrm{mg} \cdot \mathrm{kg}^{-1} \cdot \mathrm{min}^{-1} \text { infusion for } 24 \mathrm{~h} \text {, then } \\
1 \mathrm{mg} \cdot \mathrm{kg}^{-1} \cdot \mathrm{min}^{-1} \text { infusion for } 48 \mathrm{~h} \\
\text { Placebo IV bolus and infusion of identical volumes } \\
\text { of saline }\end{array}$ & PCA morphine for post-op pain & Yes & $\begin{array}{l}\text { Preventive effect; significantly reduced area } \\
\text { of punctate hyperalgesia in the KET } \\
\text { group up to seventh postoperative day } \\
\text { and reduced wind-up pain on Day } 3\end{array}$ \\
\hline
\end{tabular}


Table 3. (Continued)

\begin{tabular}{|c|c|c|c|c|c|}
\hline Study & $\begin{array}{l}\text { Quality score } \\
\qquad(0-5)\end{array}$ & No. Patients/procedure & $\begin{array}{l}\text { Comadmin } \\
\text { opioid }\end{array}$ & $\begin{array}{l}\text { Groups } \\
\text { (treatment combination) }\end{array}$ & \\
\hline Lauretti (121) & 3 & $60 /$ anterior and posterior vaginoplasty & No & IV midazolam pre-med $0.05 \mathrm{mg} / \mathrm{kg}+$ study drug & \\
\hline
\end{tabular}

$\begin{array}{lll}\text { Tverskoy (132) } & 3 & 27 / \mathrm{TAH}\end{array}$

Tanaka (131)

4

$66 /$ minor pediatric surgery

Subramaniam (130)

Mathisen (122)

Papaziogas (126)

Jaksch (118)

Dahl (114)

$89 / \mathrm{TAH}$

\section{Kathirvel (119)}

Huang (117)

Roytblat (128)

Kirdemir (120)
4

60/laparoscopic cholecystectomy
Yes

Midazolam $2 \mathrm{mg}$ IV pre-med GA with;

G1: fentanyl

G2: KET

G3: control

Yes $\quad$ PR pre-med study drug pre-GA;

G1: midazolam

G2: KET: $5 \mathrm{mg} / \mathrm{kg}$

G3: KET: $7 \mathrm{mg} / \mathrm{kg}$

G4: KET: $10 \mathrm{mg} / \mathrm{kg}$

Yes $\quad$ Pre-med diazepam $10 \mathrm{mg} 2 \mathrm{~h}$ pre-ind

$10 \mathrm{~mL}$ epidural study drug

G1: MORep

G2: $\mathrm{KET}+\mathrm{MORep}$

Yes Pre-ind midazolam $2 \mathrm{mg}$ IV

GA plus;

PRE: (R)-KET

POST: (R)-KET placebo; saline

Yes Oral diazepam $0.15 \mathrm{mg} / \mathrm{kg} 1 \mathrm{~h}$ pre-op GA plus;

G1: pre-inc placebo

G2: pre-inc placebo + Ropiv $0.1 \%$ infusion

G3: pre-inc KET + Ropiv $0.1 \%$ infusion

Yes Oral midazolam $7.5 \mathrm{mg}$ pre-med $1 \mathrm{~h}$ pre-inc GA plus; KET or saline

Yes Midazolam $0.07 \mathrm{mg} / \mathrm{kg} \mathrm{IM} 1 \mathrm{~h}$ pre-op GA plus;

G1: placebo

G2: pre-inc KET

G3: KET at skin closure

No Diazepam $0.2 \mathrm{mg} / \mathrm{kg}$ PO $2 \mathrm{~h}$ pre - op

Spinal anesthesia with;

Bupiv alone

Bupiv + KET

Yes Spinal anesthesia +

G1: IA saline

G2: IM KET $0.5 \mathrm{mg} / \mathrm{kg}$

G3: IA KET $0.5 \mathrm{mg} / \mathrm{kg}$

$\mathrm{GA}+$

G1: KET $0.15 \mathrm{mg} / \mathrm{kg}$ IV

G2: saline

Yes

$\mathrm{GA}+$ thoracic epidural with $12,5 \mathrm{mg}$ Bupiv +

G1: $50 \mathrm{mg}$ KET

G2: $0.5 \mathrm{mg}$ neostigmine

G3: saline control 
Table 3. (Continued)

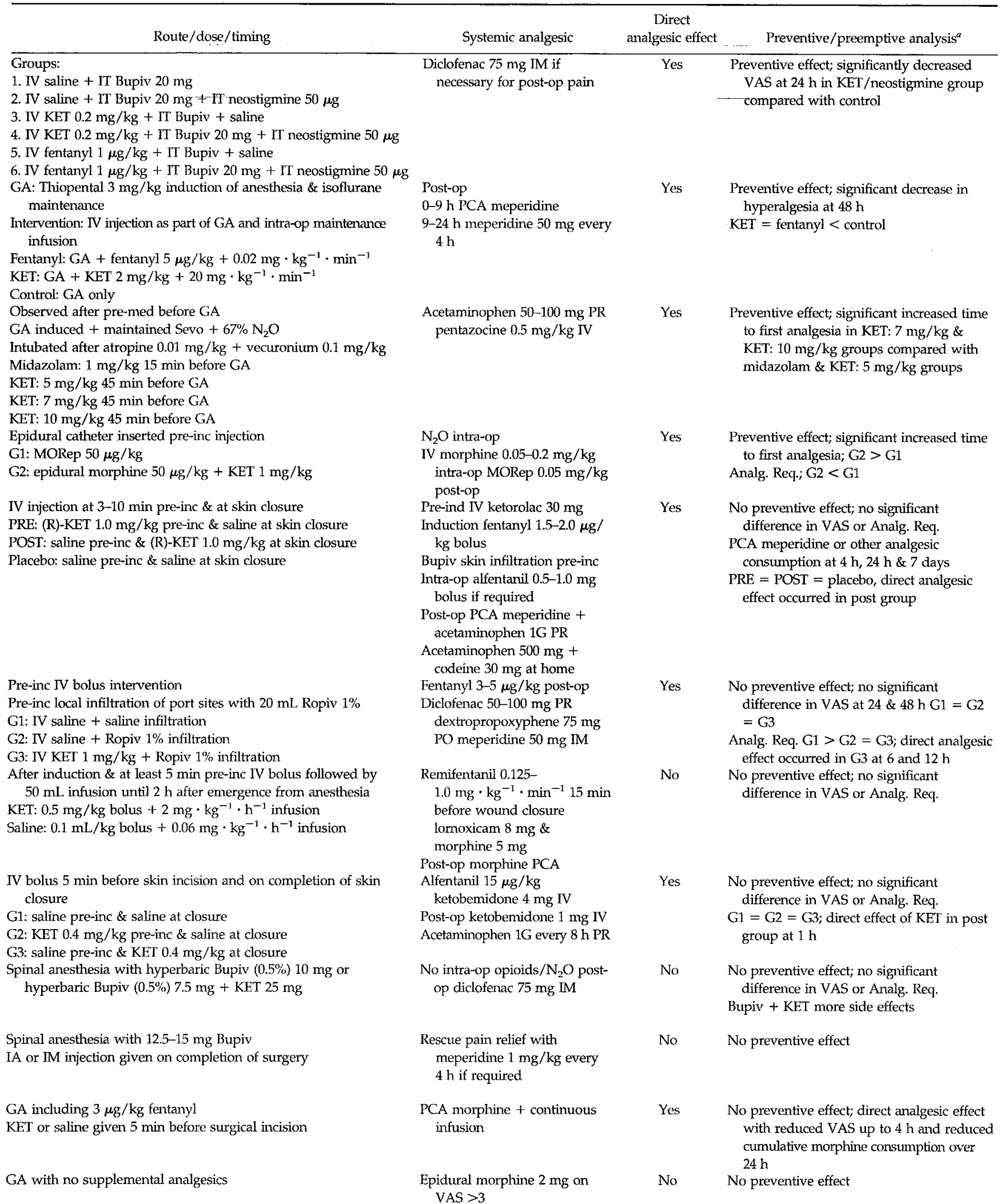


Table 3, (Continued)

\begin{tabular}{|c|c|c|c|c|}
\hline Study & $\begin{array}{l}\text { Quality score } \\
(0-5)\end{array}$ & No. Patients/procedure & $\begin{array}{l}\text { Co-admin } \\
\text { opioid }\end{array}$ & $\begin{array}{c}\text { Groups } \\
\text { (treatment combination) }\end{array}$ \\
\hline Peat (127) & 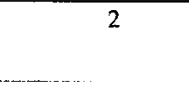 & $20 / \mathrm{TAH}$ & Yes & $\begin{array}{l}\text { Epidural after induction of GA } \\
\text { G1: KET } \\
\text { G2: diamorphine }\end{array}$ \\
\hline Wilder-Smith (135) & 4 & $45 / \mathrm{TAH}$ & Yes & $\begin{array}{l}\text { Before \& after induction; } \\
\text { G1: fentanyl } \\
\text { G2: magnesium } \\
\text { G3: KET }\end{array}$ \\
\hline
\end{tabular}

Co-admin = coadministered; Pre-med $=$ premedication; $\mathrm{GA}=$ general anesthesia; $\mathrm{MORep}=$ epidural morphine; $\mathrm{KET}=\mathrm{ketamine}$; Bupiv $=$ bupivacaine Ropiv $=$ ropivacaine; Sevo $=$ sevoflurane $\mathrm{SC}=$ subcutaneous; $\mathrm{PO}=$ per oral; $\mathrm{PR}=$ per rectum; $\mathrm{COMB}=$ combination; $\mathrm{PCA}=$ patient-controlled analgesia; VAS = visual analog scale; Analg. Req. = analgesic requirement; PACU = postanesthesia care unit; Pre-ind $=$ pre-induction; Pre-op $=$ preoperative; Pre-inc $=$ preincision; Post-inc $=$ postincision; Intra-op $=$ during surgery; Post-op $=$ after sturgery; $\mathrm{PCEA}=$ patient-controlled epidural analgesia; TCI $=$ target-controlled infusion; $\mathrm{TT}=$ intrathecal; $\mathrm{IA}=$ intraarticular; $\mathrm{ACL}=$ anterior cruciate ligament; $\mathrm{TAH}=$ total abdominal hysterectomy; $\mathrm{G}=$ group; Pre-GA $=$ before general anesthesia; PRE = before; POST = after; TCI = target-controlled infusion; PRN = as needed; NSAID = nonsteroidal antiinflammatory drug.

"Preventive analysis column concerns pain and/or analgesic consumption only beyond five half-lives of $N$-methyl-D-aspartate antagonist administration.

Adverse effects related to opioids were described in 11 of 12 studies, but no statistical difference was determined between groups. One study did not document adverse effects (147).

Four studies examined magnesium, and none demonstrated a preventive analgesic benefit (Table 5). Two of the four studies did not demonstrate a direct analgesic effect. Surgical type was limited to major abdominal or pelvic surgery, and all studies coadministered an opioid. Magnesium was administered by the IV route in all four studies. All studies documented opioid-related adverse effects but no statistical difference was found between groups.

\section{Discussion}

Adherence to the narrow definition of preemptive analgesia that currently dominates the literature may have led to a large proportion of negative results. This is especially true for studies that did not include a placebo control group to control for the possibility that the presurgical and postsurgical interventions provided an equal overall benefit in reducing central sensitization $(7,154)$. This methodological shortcoming has limited the potential clinical utility of the narrow definition because central sensitization may be induced by noxious stimuli throughout the perioperative period and not only by skin incision $(7,154)$. The limited clinical utility of the narrow definition of preemptive analgesia was demonstrated by a recent systematic review (6).

Preventive analgesia provides a broader, more clinically relevant concept in which the administration of a drug at any point in the perioperative period and the presumed associated reduction in central sensitization may reduce pain, analgesic consumption, or both beyond the clinical activity of the target drug. The NMDA antagonists would appear to be potentially useful drugs in this regard because of their effect in reducing central hypersensitivity and wind-up-like states in humans.

The results of this systematic review showed that ketamine and dextromethorphan produced a significant preventive analgesic benefit in $58 \%$ and $67 \%$ of studies, respectively. This is in addition to the benefit that in all positive preventive studies, a direct analgesic benefit of the drug occurred in the early postoperative period. It is interesting that in a large proportion $(56 \%)$ of the studies that did not find a preventive analgesic effect, a direct effect of the target drug also was absent. This strongly suggests that central sensitization was unaffected by these interventions, both immediately and in the longer term.

NMDA antagonists may reduce pain, opioid consumption, or both by two non-mutually exclusive mechanisms. The first is the more widely recognized reduction in central hypersensitivity, but NMDA antagonists have also been seen to reduce opioid tolerance in many animal and human studies. In this review, 22 ketamine and 11 dextromethorphan studies coadministered opioid analgesics with the NMDA antagonists. The analgesic benefit or reduction in opioid consumption in these studies therefore may have been due, at least in part, to a reduction of acute opioid tolerance. The other three positive studies (two ketamine and one dextromethorphan) did not coadminister opioid with the NMDA antagonist, suggesting that the reduction in pain intensity or analgesic use was due to an NMDA-mediated reduction in central sensitization brought about by the preventive analgesic intervention (although other possibilities include effects due to drug action at other receptor sites).

Many surgical procedures were included in both positive and negative studies, and there did not appear to be one specific procedure that yielded more benefit than any other. In the dextromethorphan studies, all four negative studies used the oral route, and in two of these trials at smaller doses of drug, there was no direct analgesic effect of the intervention. 
Table 3. (Continued)

\begin{tabular}{|c|c|c|c|}
\hline Route/dose/timing & Systemic analgesic & $\begin{array}{c}\text { Direct } \\
\text { analgesic effect }\end{array}$ & Preventive/preemptive analysis ${ }^{a}$ \\
\hline $\begin{array}{l}\text { Epidural injection during closure of wound } \\
\text { G1: KET; } 30 \mathrm{mg} \text { in } 3 \mathrm{~mL} \text { saline } \\
\text { G2: diamorphine; } 5 \mathrm{mg} \text { in } 3 \mathrm{~mL} \text { saline }\end{array}$ & Intra-op fentanyl $3 \mu \mathrm{g} / \mathrm{kg}$ & No & No preventive effect \\
\hline $\begin{array}{l}3 \mathrm{~min} \text { pre-ind IV bolus intervention } \\
5 \mathrm{~min} \text { pre-inc IV bolus intervention } \\
\mathrm{G} 1: \text { fentanyl } 1.5 \mu \mathrm{g} / \mathrm{kg}+0.75 \mu \mathrm{g} / \mathrm{kg} \\
\text { G2: magnesium } 20 \mathrm{mg} / \mathrm{kg}+10 \mathrm{mg} / \mathrm{kg} \\
\text { G3: KET } 0.5 \mathrm{mg} / \mathrm{kg}+0.25 \mathrm{mg} / \mathrm{kg}\end{array}$ & Morphine PCA & No & $\begin{array}{l}\text { No preventive effect, no significant difference } \\
\text { in VAS or Analg. Req. between groups }\end{array}$ \\
\hline
\end{tabular}

It may be that dextromethorphan should be administered parenterally in a dose of at least $1 \mathrm{mg} / \mathrm{kg}$ for maximal preventive effect. A variety of doses of ketamine, from 0.15 to $1 \mathrm{mg} / \mathrm{kg}$, were used, although the spread of doses was similar in both positive and negative studies.

Magnesium demonstrated no preventive analgesic effect in the four studies examined. It is difficult to understand why magnesium should have less effect than other drugs. It is possible either that the magnesium is removed from extracellular fluid rapidly or that the ion is specific to the NMDA receptor channel and does not influence the receptor sites to which other NMDA antagonists bind and thus reduce pain, analgesic consumption, or both. It is important to note that in two of four studies, the administration of magnesium did not demonstrate any direct benefit (pain or analgesic reduction) and that, therefore, it is unlikely to have shown effects later in time.

This is the first systematic review to attempt to evaluate the efficacy of preventive analgesia by examining the analgesic benefit five half-lives beyond analgesic administration. It was critical to select this time point because unlike with most studies of preemptive analgesia, preventive analgesia does not involve a postincisional analgesic intervention. We chose five half-lives to exclude as much as possible any direct effect of the NMDA antagonist. However, to avoid excluding most studies, we chose a point at which $<5 \%$ of the plasma drug concentration would remain. We could be criticized for being overly stringent and might have chosen, for example, three half-lives. In fact, changing the criterion to three half-lives would lead to inclusion of an additional six studies: two of these were negative (one dextromethorphan and one magnesium), and four, all using ketamine, were positive. Therefore, changing the cutoff to three half-lives would actually strengthen our review for the ketamine result, slightly weaken the dextromethorphan result, and leave the magnesium result unchanged.

This systematic review was limited to Englishlanguage reports and therefore may be missing data from important studies published in other languages. However, it has been reported that language-limited reports do not lead to biased estimates of intervention effectiveness (155). If the same holds true for the field of preventive analgesia, then our exclusion of the nonEnglish literature would be not be expected to alter our findings and conclusions.

A number of areas remain for future investigation with the NMDA antagonists. NMDA receptors have been isolated in the peripheral nervous system, and NMDA antagonists have been demonstrated to produce analgesic benefit in animals and volunteers (156158). Further research is required to determine benefit in the clinical setting.

Many studies coadminister NMDA antagonists with opioid analgesics and may produce benefits through a reduction in opioid tolerance (159). Further research is required to determine whether NMDA antagonist-mediated analgesia is effected through reduction in opioid tolerance or whether these drugs have analgesic benefit in isolation. Future studies should also focus on design issues, such as appropriate control groups, standardization of pain assessment, and analgesic consumption data collection (10), to allow for quantitative systematic review and meta-analysis.

In most studies included in this systematic review, the perioperative administration of ketamine and dextromethorphan reduced pain, analgesic consumption, or both immediately and beyond the clinical duration of action of the drugs used preventively. The most likely mechanism is a reduction in NMDA receptormediated central sensitization. 
Table 4. Studies Examining Dextromethorphan That Met Inclusion Criteria

\begin{tabular}{|c|c|c|c|c|}
\hline Study & $\begin{array}{l}\text { Quality score } \\
\quad(0-5)\end{array}$ & No. Patients/procedure & $\begin{array}{l}\text { Co-admin } \\
\text { opioid }\end{array}$ & $\begin{array}{l}\text { Groups } \\
\text { (treatment combination) }\end{array}$ \\
\hline Helmy (138) & 4 & $60 /$ upper abdominal surgery & $\ldots$ & $\begin{array}{l}\text { GA plus; } \\
\text { PRE: Dex/saline } \\
\text { POST: saline/Dex } \\
\text { Control: saline/saline }\end{array}$ \\
\hline Chia (136) & 4 & $60 /$ lower abdominal surgery & Yes & $\begin{array}{l}\text { GA plus; } \\
\text { PRE: Dex/saline } \\
\text { POST: saline/Dex }\end{array}$ \\
\hline Wu (146) & 3 & 60/upper abdominal surgery & Yes & $\begin{array}{l}\text { GA plus; } \\
\text { Control } \\
\text { Dex } 10 \mathrm{mg} \\
\text { Dex } 20 \mathrm{mg} \\
\text { Dex } 40 \mathrm{mg}\end{array}$ \\
\hline Kawamała (147) & 3 & $36 /$ tonsillectomy & No & $\begin{array}{l}\text { GA plus; } \\
\text { Control } \\
\text { Dex } 30 \mathrm{mg}\end{array}$ \\
\hline Weinbrown (143) & 3 & $\begin{array}{l}\text { 50/day surgery, inguinal hemiorrhaphy, } \\
\text { lower limb arthroscopy }\end{array}$ & Yes & $\begin{array}{l}\text { Single-shot epidural lidocaine plus; } \\
\text { Control } \\
\text { Dex } 60 \mathrm{mg} \\
\text { Dex } 90 \mathrm{mg}\end{array}$ \\
\hline Weinbroum (144) & 4 & $\begin{array}{l}75 / \text { day surgery, inguinal herniorrhaphy, } \\
\text { lower limb arthroscopy }\end{array}$ & Yes & $\begin{array}{l}\text { LA; single-shot epidural lidocaine } 1.6 \% 16 \mathrm{~mL} \\
\mathrm{LA}+\text { control } \\
\text { GA + control } \\
\text { LA + Dex } 90 \mathrm{mg} \\
\text { GA + Dex } 90 \mathrm{mg}\end{array}$ \\
\hline Henderson (139) & 5 & 47/TAH & Yes & $\begin{array}{l}\text { GA plus: } \\
\text { G1: Dex } \\
\text { G2: placebo control }\end{array}$ \\
\hline Wu (145) & 2 & 90/laparoscopic cholecystectomy & Yes & $\begin{array}{l}\text { GA plus; } \\
\text { Control-CPM } 20 \mathrm{mg} \text { pre-op } \\
\text { Group A-Dex } 40 \mathrm{mg} \text { intra-op } \\
\text { Group B-Dex } 40 \mathrm{mg} \text { pre-incision }\end{array}$ \\
\hline McConaghy (141) & 5 & 53/TAH & Yes & $\begin{array}{l}\text { GA plus; } \\
\text { G1: Dex } \\
\text { G2: placebo }\end{array}$ \\
\hline Ilkjaer (153) & 4 & 50/TAH & Yes & $\begin{array}{l}\text { GA plus; } \\
\text { G1: Dex } \\
\text { G2: placebo }\end{array}$ \\
\hline Grace (137) & 4 & 37/laparotomy & Yes & $\begin{array}{l}\text { GA plus; } \\
\text { Pre-med } \\
\text { G1: Dex } \\
\text { G2: placebo }\end{array}$ \\
\hline Rose (142) & 5 & 57/adenotonsillectomy (pediatric) & Yes & $\begin{array}{l}\text { GA plus: } \\
\text { G1: Dex } 0.5 \mathrm{mg} / \mathrm{kg} \\
\text { G2: Dex } 1.0 \mathrm{mg} / \mathrm{kg} \\
\text { G3: placebo }\end{array}$ \\
\hline
\end{tabular}

Co-admin $=$ coadministered $;$ Dex $=$ dextromethorphan; $\mathrm{PO}=$ per oral $; \mathrm{PCA}=$ patient-controlled analgesia; Post-op $=$ postoperative $;$ Pre-op $=$ preoperative Pre-med = premedication; Analg. Req. = analgesic requirement; VAS = visual analog scale; $P R N=$ on demand; $L A=$ local anesthetic; $C P M=$ chlorpheniramine; CHEOPS = Children's Hospital of Eastem Ontario Pain Scale; TAH = total abdominal hysterectomy; $G A=$ general anesthesia; $G=$ group; intra-op $=$ during surgery; pre $=$ before; post $=$ after; $P A C U=$ postanesthesia care unit; $P R=$ per rectum.

a Preventive analysis column concerns pain and/or analgesic consumption only beyond five half-lives of $N$-methyl-D-aspartate antagonist administration.

\section{References}

1. Fisher K, Coderre TJ, Hagen NA. Targeting the N-methyl-Daspartate receptor for chronic pain management: preclinical animal studies, recent clinical experience and future research directions. J Pain Symptom Manage 2000;20:358-73.
2. Schmid RL, Sandler AN, Katz J. Use and efficacy of low-dose ketamine in the management of acute postoperative pain: a review of current techniques and outcomes. Pain 1999;82: $111-25$.

3. Wall PD. The prevention of postoperative pain. Pain 1988;33: 289-90. 
Table 4. (Continued)

\begin{tabular}{|c|c|c|c|}
\hline Route/dose/timing & Systemic analgesic & $\begin{array}{l}\text { Direct } \\
\text { analgesic benefit }\end{array}$ & Preventive/preemptive analysis" \\
\hline $\begin{array}{l}\text { IM injection intervention; } 30 \text { min pre-incision } \\
\text { and then } 30 \mathrm{~min} \text { before end of surgery } \\
\text { PRE: Dex } 120 \mathrm{mg} \text { M then saline IM-- } \\
\text { POST: saline IM then Dex } 120 \mathrm{mg} \text { IM } \\
\text { Placebo: saline IM then saline IM }\end{array}$ & $\begin{array}{l}\text { Fentanyl } 2 \mu \mathrm{g} / \mathrm{kg} \\
\text { Post-op meperidine PCA }\end{array}$ & Yes & $\begin{array}{l}\text { Preemptive effect; median pain scores similar } \\
\text { except at } 6 \mathrm{~h} \\
\text { 24 } \mathrm{h} \text { PCA consumption significantly reduced in } \\
\text { PRE group }\end{array}$ \\
\hline $\begin{array}{l}\text { IV infusion } \\
\text { Dex: } 5 \mathrm{mg} / \mathrm{kg} \text { in } 300 \mathrm{~mL} \text { saline } / 30 \mathrm{~min} \\
\text { Saline: } 300 \mathrm{~mL} \text { saline } / 30 \mathrm{~min} \\
\text { PRE: } 30 \mathrm{~min} \text { pre-induction } \\
\text { POST: during skin closure }\end{array}$ & $\begin{array}{l}\text { Fentanyl } 3 \mu \mathrm{g} / \mathrm{kg} \\
\text { Post-op PCA } \\
\text { Morphine }\end{array}$ & Yes & $\begin{array}{l}\text { Preemptive effect; morphine requirements higher } \\
\text { in POST group than PRE group on Day } 1 \text { and } 2\end{array}$ \\
\hline $\begin{array}{l}\text { IM injection } 30 \mathrm{~min} \text { pre-incision } \\
\text { Control: com } 20 \mathrm{mg} \\
\text { DEX-10: Dex } 10 \mathrm{mg} \\
\text { DEX-20: Dex } 20 \mathrm{mg} \\
\text { DEX-40: Dex } 40 \mathrm{mg}\end{array}$ & $\begin{array}{l}\text { Fentanyl } 2 \mu \mathrm{g} / \mathrm{kg} \\
\text { Post-op PCA } \\
\text { Morphine }\end{array}$ & Yes & $\begin{array}{l}\text { Preventive effect; all data showed dose-dependent } \\
\text { better pain relief in Dex-premedicated patients }\end{array}$ \\
\hline $\begin{array}{l}\text { Oral pre-med } 60 \mathrm{~min} \text { pre-induction } \\
\text { Control: starch tablet } \\
\text { DEX-30: Dex } 30 \mathrm{mg} \\
\text { DEX-45: Dex } 45 \mathrm{mg}\end{array}$ & $\begin{array}{l}\text { No intra-op opioids } \\
\text { Post-op loxoprofen } 60 \mathrm{mg} \text { every } 8 \mathrm{~h} \text { PO + } \\
\text { diclofenac } 50 \mathrm{mg} \text { PRN suppository }\end{array}$ & Yes & $\begin{array}{l}\text { Preventive effect; significantly lower VAS and } \\
\text { Analg. Req. in Dex compared with control } \\
\text { DEX-30 = DEX-45 }\end{array}$ \\
\hline $\begin{array}{l}\text { Oral capsule } \\
90 \mathrm{~min} \text { pre-induction } \\
\text { Control: placebo } \\
\text { DEX-60: Dex } 60 \mathrm{mg} \\
\text { DEX-90: Dex } 90 \mathrm{mg}\end{array}$ & $\begin{array}{l}\text { Post-op analgesia } \\
\text { Morphine PCA first } 2 \mathrm{~h} \text { in PACU } \\
\text { Diclofenac } 75 \mathrm{mg} \text { IM PRN next } 4 \mathrm{~h} \text { in PACU } \\
\text { Diclofenac } 50 \mathrm{mg} \text { PO PRN after discharge }\end{array}$ & Yes & $\begin{array}{l}\text { Preventive effect; significantly lower Analg. Req. } \\
\text { and VAS in DEX-60 and -90 compared with } \\
\text { control }\end{array}$ \\
\hline $\begin{array}{l}\text { Oral tablet } 90 \mathrm{~min} \text { before surgery } \\
\text { LA + placebo } \\
\text { GA + placebo } \\
\text { LA + Dex } 90 \mathrm{mg} \\
\text { GA + Dex } 90 \mathrm{mg}\end{array}$ & $\begin{array}{l}\text { Intra-op fentanyl } 2.5 \mu \mathrm{g} / \mathrm{kg} \\
\text { Post-op analgesia } \\
\text { Morphine PCA } \\
\text { Diclofenac } 75 \mathrm{mg} \text { IM PRN } \\
\text { Diclofenac } 50 \mathrm{mg} \text { PO PRN after discharge }\end{array}$ & Yes & $\begin{array}{l}\text { Preventive effect; } 50 \% \text { lower Analg. Req. and VAS } \\
\text { in DEX-90 versus control } \pm \text { GA or LA }\end{array}$ \\
\hline $\begin{array}{l}\mathrm{GA}+ \\
\mathrm{G} 1: \text { Dex } 40 \mathrm{mg} \text { pre-med }+4 \mathrm{~h} \text { post-surgery } \\
\text { and then every } 8 \mathrm{~h} \text { for next } 48 \mathrm{~h} \\
\text { G2: placebo control tablets as } \mathrm{G} 1\end{array}$ & $\begin{array}{l}\text { Intra-op fentanyl } 1.5 \mu \mathrm{g} / \mathrm{kg} \\
\text { PCA morphine for postoperative pain }\end{array}$ & Yes & $\begin{array}{l}\text { Preventive effect; decreased VAS on movement } \\
\text { and analgesic consumption at } 72 \mathrm{~h}\end{array}$ \\
\hline $\begin{array}{l}\text { Control-CPM } 20 \mathrm{mg} \text { IM } 30 \mathrm{~min} \text { pre-op } \\
\text { Group A: Dex } 40 \mathrm{mg} \text { IM after removal of } \\
\text { gallbladder } \\
\text { Group B-Dex } 40 \mathrm{mg} \text { IM } 30 \mathrm{~min} \text { pre-op }\end{array}$ & $\begin{array}{l}\text { Fentanyl } 2 \mu \mathrm{g} / \mathrm{kg} \text { intra-op } \\
\text { Meperidine } 1 \mathrm{mg} / \mathrm{kg} \mathrm{IM} \text { post-op }\end{array}$ & Yes & $\begin{array}{l}\text { Preemptive effect; time to first analgesia } \\
\text { significant Group B > Group A > control }\end{array}$ \\
\hline $\begin{array}{l}\text { Oral capsule } \\
\text { Night before surgery and } 1-2 \mathrm{~h} \text { pre-op and } 8 \text {, } \\
16,24 \mathrm{~h} \text { post-op } \\
\text { G1: Dex } 27 \mathrm{mg} \\
\text { G2: placebo }\end{array}$ & $\begin{array}{l}\text { Morphine } 0.1-0.15 \mathrm{mg} / \mathrm{kg} \\
\text { Post-op PCA morphine }\end{array}$ & No & $\begin{array}{l}\text { No preventive effect; no significant difference in } \\
\text { hyperalgesia/Analg. Req./VAS at } 48 \mathrm{~h} \text { or } 1 \mathrm{mo}\end{array}$ \\
\hline $\begin{array}{l}\text { Oral tablet } 1 \mathrm{~h} \text { pre-op } \\
\text { G1: Dex } 150 \mathrm{mg} \\
\text { G2: placebo tablet }\end{array}$ & $\begin{array}{l}\text { Fentanyl } 300 \mu \mathrm{g}+50 \mu \mathrm{g} / 30 \mathrm{~min} \text { boluses } \\
\text { Post-op PCA morphine }\end{array}$ & Yes & $\begin{array}{l}\text { No preventive effect; no significant difference in } \\
\text { hyperalgesia/Analg. Req./side effects at } 24 \mathrm{~h} \\
\text { or } 3 \text { mo } \\
\text { Reduction in morphine consumption in Dex } \\
\text { group in first } 4 \mathrm{~h}=\text { direct analgesic effect }\end{array}$ \\
\hline $\begin{array}{l}\text { Oral capsule } \\
\text { Night before surgery and } 1 \mathrm{~h} \text { pre-op } \\
\text { G1: Dex } 60 \mathrm{mg} \\
\text { G2: placebo }\end{array}$ & PCA morphine & Yes & $\begin{array}{l}\text { No preventive effect; reduction in early morphine } \\
\text { consumption in Dex group }=\text { direct analgesic } \\
\text { effect } \\
\text { No significant difference post-op Analg. Req. at } \\
24 \mathrm{~h}\end{array}$ \\
\hline $\begin{array}{l}\text { Oral preparation } 60 \mathrm{~min} \text { pre-op } \\
\text { G1: Dex } 0.5 \mathrm{mg} / \mathrm{kg} \\
\text { G2: Dex } 1.0 \mathrm{mg} / \mathrm{kg} \\
\text { G3: placebo }\end{array}$ & $\begin{array}{l}\text { IV morphine } 0.075 \mathrm{mg} / \mathrm{kg} \\
\text { PR acetaminophen } 25-35 \mathrm{mg} / \mathrm{kg}\end{array}$ & No & $\begin{array}{l}\text { No preventive effect; no significant difference in } \\
\text { Analg. Req./CHEOPS/VAS/side effects at } 24 \mathrm{~h}\end{array}$ \\
\hline
\end{tabular}

4. Katz J. George Washington Crile, anoci-association, and preemptive analgesia. Pain 1993;53:243-5.

5. McQuay HJ. Pre-emptive analgesia. Br I Anaesth 1992;69:1-3.

6. Moiniche S, Kehlet H, Dahl JB. A qualitative and quantitative systematic review of preemptive analgesia for postoperative pain relief: the role of timing of analgesia. Anesthesiology 2002;96:725-41.

7. Katz J. Pre-emptive analgesia: evidence, current status and future directions. Eur J Anaesthesiol Suppl 1995;10:8-13.

8. Kissin I. Preemptive analgesia: terminology and clinical relevance. Anesth Analg 1994;79:809-10.
9. Katz J, McCartney CJ. Update on pre-emptive analgesia. Curr Opin Anesthesiol 2002;15:435-41.

10. Katz J. Timing of treatment and pre-emptive analgesia. In: Rice A, Warfield C, Justins D, Eccleston C, eds. Clinical pain management. Vol 1: Acute pain. London: Arnold, 2003:113-63.

11. Jadad AR, Moore RA, Carroll D, et al. Assessing the quality of reports of randomized clinical trials: is blinding necessary? Control Clin Trials 1996;17:1-12.

12. Clements JA, Nimmo WS, Grant IS. Bioavailability, pharmacokinetics, and analgesic activity of ketamine in humans. J Pharm Sci 1982;71:539-42. 
Table 5. Studies That Examined Magnesium and Met Inclusion Criteria

\begin{tabular}{|c|c|c|c|c|}
\hline Study & $\begin{array}{l}\text { Quality score } \\
\qquad(0-5)\end{array}$ & No. Patients/procedure & $\begin{array}{l}\text { Co-admin } \\
\text { opioid }\end{array}$ & $\begin{array}{l}\text { Groups } \\
\text { (treatment combination) }\end{array}$ \\
\hline Zarauza (150) & 4 & 92/elective colorectal surgery & Yes & $\begin{array}{l}\text { GA plus; } \\
\text { Group C: control } \\
\text { Group NF: nifedipine } \\
\text { Group NM: nimodipine } \\
\text { Group } \mathrm{MG}: \mathrm{MgSO}_{4}\end{array}$ \\
\hline
\end{tabular}

\begin{tabular}{|c|c|c|c|c|}
\hline Tramer (149) & 5 & 42/elective $\mathrm{TAH}$ & Yes & $\begin{array}{l}\text { GA plus; } \\
\text { G1: control } \\
\text { G2: } \mathrm{MgSO}_{4}\end{array}$ \\
\hline Ko (148) & 3 & $\begin{array}{l}58 \text { / elective TAH with lower } \\
\text { midline incision }\end{array}$ & Yes & $\begin{array}{l}\text { GA plus; } \\
\text { G1: control } \\
\text { G2: } \mathrm{MgSO}_{4}\end{array}$ \\
\hline Wilder-Smith (151) & 4 & 24/elective TAH & Yes & $\begin{array}{l}\text { Fentanyl } 1 \mu \mathrm{g} / \mathrm{kg} \mathrm{IM} \\
1 \text { h pre-op } \\
\text { G1: placebo } \\
\text { G2: } \mathrm{MgSO}_{4}\end{array}$ \\
\hline
\end{tabular}

Co-admin $=$ coadministered; $\mathrm{GA}=$ general anesthesia; VAS $=$ visual analog scale; Analg. Req. $=$ analgesic requirement; $\mathrm{PCEA}=$ patient-controlled epidural analgesia; Post-op = postoperative; IVI = IV infusion; $\mathrm{TAH}=$ total abdominal hysterectomy; $\mathrm{MgSO}_{4}=$ magnesium sulphate; pre-op = before surgery; pre = before; post $=$ after; pre-med $=$ premedication; intra-op $=$ intraoperative.

"Preventive analysis column concerns pain and/or analgesic consumption only beyond five half-lives of $N$-methyl-D-aspartate antagonist administration.

13. Woodworth JR, Dennis SR, Moore L, Rotenberg KS. The polymorphic metabolism of dextromethorphan. J Clin Pharmacol 1987;27:139-43.

14. Eap CB, Buclin T, Baumann P. Interindividual variability of the clinical pharmacokinetics of methadone: implications for the treatment of opioid dependence. Clin Pharmacokinet 2002;41: 1153-93.

15. Taber EB, Tan L, Chao CR, et al. Pharmacokinetics of ionized versus total magnesium in subjects with preterm labor and preeclampsia. Am J Obstet Gynecol 2002;186:1017-21.

16. Kawana $Y$, Sato $H$, Shimada $H$, et al. Epidural ketamine for postoperative pain relief after gynecologic operations: a double-blind study and comparison with epidural morphine. Anesth Analg 1987;66:735-8.

17. Kucuk N, Kizilkaya M, Tokdemir M. Preoperative epidural ketamine does not have a postoperative opioid sparing effect. Anesth Analg 1998;87:103-6.

18. Ravat F, Dorne R, Baechle JP, et al. Epidural ketamine or morphine for postoperative analgesia. Anesthesiology 1987;66: 819-22.

19. Vallejo MC, Romeo RC, Davis DJ, Ramanathan S. Propofolketamine versus propofol-fentanyl for outpatient laparoscopy: comparison of postoperative nausea, emesis, analgesia, and recovery. J Clin Anesth 2002;14:426-31.

20. Wu CT, Yeh CC, Yu JC, et al. Pre-incisional epidural ketamine, morphine and bupivacaine combined with epidural and general anaesthesia provides pre-emptive analgesia for upper abdominal surgery. Acta Anaesthesiol Scand 2000;44:63-8.

21. Yeh CC, Ho ST, Kong SS, et al. Absence of the preemptive analgesic effect of dextromethorphan in total knee replacement under epidural anesthesia. Acta Anaesthesiol Sin 2000;38: 187-93.

22. Grace RF, Lesteour T, Sala T, Stewart J. A randomized comparison of low-dose ketamine and lignocaine infiltration with ketamine-diazepam anaesthesia for post partum tubal ligation in Vanuatu. Anaesth Intensive Care 2001;29:30-3.

23. Callesen T, Bech $K$, Andersen J, et al. Pain after primary inguinal herniorrhaphy: influence of surgical technique. J Am Coll Surg 1999;188:355-9.
24. Findlow D, Aldridge LM, Doyle E. Comparison of caudal block using bupivacaine and ketamine with ilioinguinal nerve block for orchidopexy in children. Anaesthesia 1997;52:1110-3.

25. Gourlay GK, Willis RJ, Wilson PR. Postoperative pain control with methadone: influence of supplementary methadone doses and blood concentration-response relationships. Anesthesiology 1984;61:19-26.

26. Hager $H$, Marhofer $P$, Sitzwohl $C$, et al. Caudal clonidine prolongs analgesia from caudal $\mathrm{S}(+)$-ketamine in children. Anesth Analg 2002;94:1169-72.

27. Johnston P, Findlow D, Aldridge LM, Doyle E. The effect of ketamine on $0.25 \%$ and $0.125 \%$ bupivacaine for caudal epidural blockade in children. Paediatr Anaesth 1999;9:31-4.

28. Koinig $\mathrm{H}$, Marhofer $\mathrm{P}$, Krenn $\mathrm{CG}$, et al. Analgesic effects of caudal and intramuscular $S(+)$-ketamine in children. Anesthesiology 2000;93:976-80.

29. Naguib M, Adu-Gyamfi $Y$, Absood GH, et al. Epidural ketamine for postoperative analgesia. Can Anaesth Soc J 1986;33: $16-21$.

30. Parbrook GD. Post-operative pain relief: comparison of methadone and morphine when used concurrently with nitrousoxide analgesia. BMJ 1966;2:616-8.

31. Prieto-Alvarez P, Tello-Galindo I, Cuenca-Pena J, et al. Continuous epidural infusion of racemic methadone results in effective postoperative analgesia and low plasma concentrations. Can J Anaesth 2002;49:25-31.

32. Taura P, Fuster J, Blasi A, et al. Postoperative pain relief after hepatic resection in cirrhotic patients: the efficacy of a single small dose of ketamine plus morphine epidurally. Anesth Analg 2003;96:475-80.

33. Aggarwal A, Ganguly S, Anand VK, Patwari AK. Efficacy and safety of intravenous ketamine for sedation and analgesia during pediatric endoscopic procedures. Indian Pediatr 1998;35: 1211-4.

34. Grabinski PY, Kaiko RF, Rogers AG, Houde RW. Plasma levels and analgesia following deltoid and gluteal injections of methadone and morphine. J Clin Pharmacol 1983;23:48-55. 


\begin{tabular}{|c|c|c|c|}
\hline Route/dose/timing & Systemic analgesic & $\begin{array}{l}\text { Direct } \\
\text { analgesic benefit }\end{array}$ & Preventive analysis $^{a}$ \\
\hline $\begin{array}{l}\text { Oral tablet placebo or study drug } \\
3 \text { h before surgery }\end{array}$ & $\begin{array}{l}\text { Fentanyl } 4 \mu \mathrm{g} / \mathrm{kg} \text { bolus }+ \text { infusion } \\
\quad 1 \mathrm{mg} \cdot \mathrm{kg}^{-1} \cdot \mathrm{h}^{-1}\end{array}$ & No & $\begin{array}{l}\text { No preventive effect; no significant } \\
\text { difference }\end{array}$ \\
\hline $\begin{array}{l}<20 \mathrm{~min} \text { post-induction IV bolus }+ \text { start } 20 \mathrm{~h} \text { IV infusion } \\
\text { of placebo or study drug } \\
\text { Group C: placebo tablet }+\mathrm{IV} \text { bolus }+\mathrm{IVI} \\
\text { Group NF: nifedipine } 60 \mathrm{mg}+\text { placebo bolus }+\mathrm{IVI} \\
\text { Group NM: placebo tablet }+ \text { bolus }+ \text { nimodipine } \\
30 \mathrm{mg} \cdot \mathrm{kg}^{-1} \cdot \mathrm{h}^{-1} \mathrm{IVI} \text { over } 20 \mathrm{~h} \\
\text { Group } \mathrm{MG}: \text { placebo tablet }+\mathrm{MgSO}_{4} 30 \mathrm{mg} / \mathrm{kg} \text { bolus }+ \\
\quad 10 \mathrm{mg} \cdot \mathrm{kg}^{-1} \cdot \mathrm{h}^{-1} \mathrm{IVI} \text { over } 20 \mathrm{~h}\end{array}$ & $\begin{array}{l}\text { Post-op PCA morphine }--\cdots \\
\text { If VAS > } \\
2 \mathrm{~g} \text { propacetamol IV } \\
2 \mathrm{~g} \text { metamizole IV }\end{array}$ & & VAS/Analg. Req./side effects \\
\hline $\begin{array}{l}\text { Post-induction bolus }+\mathrm{IV} \text { infusion } 20 \mathrm{~h} \\
\mathrm{G1} \text { saline } 15 \mathrm{~mL} \text { bolus }+2.5 \mathrm{~mL} / \mathrm{h} \text { IVI } \\
\mathrm{G} 2: \mathrm{MgSO}_{4} 20 \% 15 \mathrm{~mL} \text { bolus }+2.5 \mathrm{~mL} / \mathrm{h} \text { IVI } \\
\quad(13 \mathrm{~g} \text { total dose })\end{array}$ & $\begin{array}{l}\text { Fentanyl } \\
3 \mu \mathrm{g} / \mathrm{kg} \text { at induction } \\
1.5 \mu \mathrm{g} / \mathrm{kg} \text { at } 5 \mathrm{~min} \text { before incision } \\
+1 \mu \mathrm{g} / \mathrm{kg} \text { boluses post-op PCA morphine }\end{array}$ & Yes & $\begin{array}{l}\text { No preventive effect; Analg. Req. } \\
\text { significantly reduced in } \mathrm{MgSO}_{4} \\
\text { group during first } 6 \mathrm{~h} \text { post-op but } \\
\text { not thereafter }\end{array}$ \\
\hline $\begin{array}{l}\text { IV bolus + infusion for } 6 \mathrm{~h} \\
\text { G1: saline } 0.2 \mathrm{~mL} / \mathrm{kg} \text { bolus }+ \text { IVI } \\
\text { G2: } \mathrm{MgSO}_{4} 25 \% 50 \mathrm{mg} / \mathrm{kg} \text { bolus } \\
+ \text { IVI at } 15 \mathrm{mg} \cdot \mathrm{kg}^{-1} \cdot \mathrm{h}^{-1} \text { for } 6 \mathrm{~h}\end{array}$ & $\begin{array}{l}\text { Post-op PCEA (bupivacaine } 0.05 \%+ \\
\text { fentanyl } 5 \mu \mathrm{g} / \mathrm{mL} \text { ) }\end{array}$ & No & $\begin{array}{l}\text { No preventive effect; no significant } \\
\text { difference in VAS/Analg. Req. }\end{array}$ \\
\hline $\begin{array}{l}\text { Slow IV bolus } 5 \mathrm{~min} \text { pre-induction }+ \text { continuous IV } \\
\text { infusion for } 5 \mathrm{~h} \text { post-op } \\
\text { G1: placebo } \mathrm{IV} \text { bolus }+ \text { IV infusion } \\
\text { G2: magnesium } 200 \mathrm{mg} \text { IV bolus }+200 \mathrm{mg} / \mathrm{h} \text { IVI for } 5 \mathrm{~h}\end{array}$ & $\begin{array}{l}\text { Fentanyl } 1 \mu \mathrm{g} / \mathrm{kg} \text { IM pre-med } \\
\text { Alfentanil } 15 \mu \mathrm{g} / \mathrm{kg} \text { IV bolus at induction } \\
\quad+\text { intra-op IV infusion at } \\
0.030 .05 \mathrm{mg} \cdot \mathrm{kg}^{-1} \cdot \mathrm{min}^{-1} \\
\text { Morphine PCA basal infusion } 0.5 \mathrm{mg} / \mathrm{h}+ \\
\text { bolus } 2.5 \mathrm{mg} \text { with } 10 \mathrm{~min} \text { lockout }\end{array}$ & Yes & $\begin{array}{l}\text { No preventive effect; no significant } \\
\text { difference in VAS/Analg. Req. } \\
\text { except at } 1 \mathrm{~h} \text { post-op }\end{array}$ \\
\hline
\end{tabular}

35. Hartvig $P$, Larsson E, Joachimsson PO. Postoperative analgesia and sedation following pediatric cardiac surgery using a constant infusion of ketamine. J Cardiothorac Vasc Anesth 1993; 7:148-53.

36. Islas JA, Astorga J, Laredo M. Epidural ketamine for control of postoperative pain. Anesth Analg 1985;64:1161-2.

37. Ito $Y$, Ichiyanagi $K$. Post-operative pain relief with ketamine infusion. Anaesthesia 1974;29:222-6.

38. Mathisen LC, Skjelbred P, Skoglund LA, Oye I. Effect of ketamine, an NMDA receptor inhibitor, in acute and chronic orofacial pain. Pain 1995;61:215-20.

39. Nyska M, Klin B, Shapira $Y$, et al. Epidural methadone for preoperative analgesia in patients with proximal femoral fractures. Br Med J (Clin Res Ed) 1986;293:1347-8.

40. Shir Y, Eimerl D, Magora F, et al. Plasma concentrations of methadone during postoperative patient-controlled extradural analgesia. Br J Anaesth 1990;65:204-9.

41. Welch DB, Hrynaszkiewicz A. Postoperative analgesia using epidural methadone: administration by the lumbar route for thoracic pain relief. Anaesthesia 1981;36:1051-4.

42. Cook B, Grubb DJ, Aldridge LA, Doyle E. Comparison of the effects of adrenaline, clonidine and ketamine on the duration of caudal analgesia produced by bupivacaine in children. $\mathrm{Br} J$ Anaesth 1995;75:698-701.

43. Schulz-Stubner S, Wettmann G, Reyle-Hahn SM, Rossaint R. Magnesium as part of balanced general anaesthesia with propofol, remifentanil and mivacurium: a double-blind, randomized prospective study in 50 patients. Eur J Anaesthesiol 2001;18:723-9.

44. Wadhwa A, Clarke D, Goodchild CS, Young D. Large-dose oral dextromethorphan as an adjunct to patient-controlled analgesia with morphine after knee surgery. Anesth Analg 2001; 92:448-54

45. Wong CS, Liaw WJ, Tung CS, et al. Ketamine potentiates analgesic effect of morphine in postoperative epidural pain control. Reg Anesth 1996;21:534-41.

46. Abdel-Ghaffar ME, Abdulatif MA, al Ghamdi A, et al. Epidural ketamine reduces post-operative epidural PCA consumption of fentanyl/bupivacaine. Can J Anaesth 1998;45:103-9.
47. Ilkjaer S, Nikolajsen L, Hansen TM, et al. Effect of i.v. ketamine in combination with epidural bupivacaine or epidural morphine on postoperative pain and wound tenderness after renal surgery. Br J Anaesth 1998;81:707-12.

48. Javery KB, Ussery TW, Steger HG, Colclough GW. Comparison of morphine and morphine with ketamine for postoperative analgesia. Can J Anaesth 1996;43:212-5.

49. Lauretti GR, Oliveira AP, Rodrigues AM, Paccola CA. The effect of transdermal nitroglycerin on spinal $S(+)$-ketamine antinociception following orthopedic surgery. J Clin Anesth 2001;13:576-81.

50. Ozbek H, Bilen A, Ozcengiz D, et al. The comparison of caudal ketamine, alfentanil and ketamine plus alfentanil administration for postoperative analgesia in children. Paediatr Anaesth 2002;12:610-6.

51. Subramaniam B, Subramaniam K, Pawar DK, Sennaraj B. Preoperative epidural ketamine in combination with morphine does not have a clinically relevant intra- and postoperative opioid-sparing effect. Anesth Analg 2001;93:1321-6.

52. Tan $\mathrm{PH}, \mathrm{Kuo} \mathrm{MC}$, Kao PF, et al. Patient-controlled epidural analgesia with morphine or morphine plus ketamine for postoperative pain relief. Eur J Anaesthesiol 1999;16:820-5.

53. Weir PS, Fee JP. Double-blind comparison of extradural block with three bupivacaine-ketamine mixtures in knee arthroplasty. Br J Anaesth 1998;80:299-301.

54. Zacharias M, Hunter KM, Baker AB. Effectiveness of preoperative analgesics on postoperative dental pain: a study. Anesth Prog 1996;43:92-6.

55. Chia $Y Y$, Liu K, Liu YC, et al. Adding ketamine in a multimodal patient-controlled epidural regimen reduces postoperative pain and analgesic consumption. Anesth Analg 1998;86: $1245-9$.

56. Dawson GS, Seidman P, Ramadan HH. Improved postoperative pain control in pediatric adenotonsillectomy with dextromethorphan. Laryngoscope 2001;111:1223-6.

57. Dich-Nielsen JO, Svendsen LB, Berthelsen P. Intramuscular low-dose ketamine versus pethidine for postoperative pain treatment after thoracic surgery. Acta Anaesthesiol Scand 1992; 36:583-7. 
58. Joachimsson PO, Hedstrand U, Eklund A. Low-dose ketamine infusion for analgesia during postoperative ventilator treatment. Acta Anaesthesiol Scand 1986;30:697-702.

59. Levanen J. Ketamine and oxycodone in the management of postoperative pain. Mil Med 2000;165:450-5.

60. Liu ST, Wu CT, Yeh CC, et al. Premedication with dextromethorphan provides posthemorrhoidectomy pain relief. Dis Colon Rectum 2000;43:507-10.

61. Marcus RJ, Victoria BA, Rushman SC, Thompson JP. Comparison of ketamine and morphine for analgesia after tonsillectomy in children. Br J Anaesth 2000;84:739-42.

62. Marhofer P, Krenn CG, Plochl W, et al. S(+)-ketamine for caudal block in paediatric anaesthesia. $\mathrm{Br} J$ Anaesth 2000;84: 341-5.

63. Maurset A, Skoglund LA, Hustveit O, Oye I. Comparison of ketamine and pethidine in experimental and postoperative pain. Pain 1989;36:37-41.

64. Murray WB, Yankelowitz SM, le Roux M, Bester HF. Prevention of post-tonsillectomy pain with analgesic doses of ketamine. S Afr Med J 1987;72:839-42.

65. Owen H, Reekie RM, Clements JA, et al. Analgesia from morphine and ketamine: a comparison of infusions of morphine and ketamine for postoperative analgesia. Anaesthesia 1987; 42:1051-6.

66. Parkhouse J, Marriott G. Postoperative analgesia with ketamine and pethidine. Anaesthesia 1977;32:285-9.

67. Reeves M, Lindholm DE, Myles PS, et al. Adding ketamine to morphine for patient-controlled analgesia after major abdominal surgery: a double-blinded, randomized controlled trial. Anesth Analg 2001;93:116-20.

68. Suzuki M, Tsueda K, Lansing PS, et al. Small-dose ketamine enhances morphine-induced analgesia after outpatient surgery. Anesth Analg 1999;89:98-103.

69. Weinbroum AA, Gorodetzky A, Nirkin A, et al. Dextromethorphan for the reduction of immediate and late postoperative pain and morphine consumption in orthopedic oncology patients: a randomized, placebo-controlled, double-blind study. Cancer 2002;95:1164-70.

70. Wong CS, Wu CT, Yu JC, et al. Preincisional dextromethorphan decreases postoperative pain and opioid requirement after modified radical mastectomy. Can J Anaesth 1999;46: 1122-6.

71. Liu ST, $\mathrm{Wu} C T$, Yeh $\mathrm{CC}$, et al. Premedication with dextromethorphan provides posthemorrhoidectomy pain relief. Dis Colon Rectum 2000;43:507-10.

72. Berde CB, Beyer JE, Boumaki MC, et al. Comparison of morphine and methadone for prevention of postoperative pain in 3- to 7-year-old children. J Pediatr 1991;119:136-41.

73. Ilkjaer S, Nielsen PA, Bach LF, et al. The effect of dextromethorphan, alone or in combination with ibuprofen, on postoperative pain after minor gynaecological surgery. Acta Anaesthesiol Scand 2000;44:873-7.

74. Richlin DM, Reuben SS. Postoperative pain control with methadone following lower abdominal surgery. J Clin Anesth 1991; 3:112-6.

75. Haynes SR, Davidson I, Allsop JR, Dutton DA. Comparison of epidural methadone with epidural diamorphine for analgesia following caesarean section. Acta Anaesthesiol Scand 1993;37: 375-80.

76. Beeby D, MacIntosh $\mathrm{KC}$, Bailey M, Welch DB. Postoperative analgesia for Caesarean section using epidural methadone. Anaesthesia 1984;39:61-3.

77. Chui PT, Gin T. A double-blind randomised trial comparing postoperative analgesia after perioperative loading doses of methadone or morphine. Anaesth Intensive Care 1992;20: $46-51$.

78. Gedney JA, Liu EH. Side-effects of epidural infusions of opioid bupivacaine mixtures. Anaesthesia 1998:53:1148-55.

79. Gourlay GK, Willis RJ, Lamberty J. A double-blind comparison of the efficacy of methadone and morphine in postoperative pain control. Anesthesiology 1986;64:322-7.
80. Jacobson L, Chabal C, Brody MC, et al. Intrathecal methadone and morphine for postoperative analgesia: a comparison of the efficacy, duration, and side effects. Anesthesiology 1989;70: $742-6$.

81. Wang JM, Knarr DC, Raj PP, Denson D. Continuous epidural methadone for the management of postoperative pain after lower abdominal surgery. Reg Anesth 1992;17:26-8.

82. Adriaenssens G, Vermeyen KM, Hoffmann VL, et al. Postoperative analgesia with i.v. patient-controlled morphine: effect of adding ketamine. Br J Anaesth 1999;83:393-6.

83. Edwards ND, Fletcher A, Cole JR, Peacock JE. Combined infusions of morphine and ketamine for postoperative pain in elderly patients. Anaesthesia 1993;48:124-7.

84. Jahangir SM, Išlam F, Aziz L. Ketamine infusion for postoperative analgesia in asthmatics: a comparison with intermittent meperidine. Anesth Analg 1993;76:45-9.

85. Koinig H, Wallner $T$, Marhofer $P$, et al. Magnesium sulfate reduces intra- and postoperative analgesic requirements. Anesth Analg 1998;87:206-10.

86. Memis D, Turan A, Karamanlioglu B, et al. The use of magnesium sulfate to prevent pain on injection of propofol. Anesth Analg 2002;95:606-8.

87. Aspinall RL, Mayor A. A prospective randomized controlled study of the efficacy of ketamine for postoperative pain relief in children after adenotonsillectomy. Paediatr Anaesth 2001; 11:333-6.

88. Buvanendran A, McCarthy RJ, Kroin JS, et al. Intrathecal magnesium prolongs fentanyl analgesia: a prospective, randomized, controlled trial. Anesth Analg 2002;95:661-6.

89. Kee WD, Khaw KS, Ma ML, et al. Postoperative analgesic requirement after cesarean section: a comparison of anesthetic induction with ketamine or thiopental. Anesth Analg 1997;85: 1294-8.

90. Naguib $M$, Sharif AM, Seraj $M$, et al. Ketamine for caudal analgesia in children: comparison with caudal bupivacaine. Br J Anaesth 1991;67:559-64.

91. Unlugenc $H$, Gunduz $M$, Ozalevli $M$, Akman $H$. A comparative study on the analgesic effect of tramadol, tramadol plus magnesium, and tramadol plus ketamine for postoperative pain management after major abdominal surgery. Acta Anaesthesiol Scand 2002;46:1025-30.

92. Yanli $Y$, Eren A. The effect of extradural ketamine on onset time and sensory block in extradural anaesthesia with bupivacaine. Anaesthesia 1996;51:84-6.

93. Levaux C, Bonhomme V, Dewandre PY, et al. Effect of intraoperative magnesium sulphate on pain relief and patient comfort after major lumbar orthopaedic surgery. Anaesthesia 2003 58:131-5.

94. Weinbroum AA. A single small dose of postoperative ketamine provides rapid and sustained improvement in morphine analgesia in the presence of morphine-resistant pain. Anesth Analg 2003;96:789-95.

95. Lee HM, Sanders GM. Caudal ropivacaine and ketamine for postoperative analgesia in children. Anaesthesia 2000;55: 806-10.

96. Cheng KI, Chu KS, Fang YR, et al. Total intravenous anesthesia using propofol and ketamine for ambulatory gynecologic laparoscopy. Kaohsiung J Med Sci 1999;15:536-41.

97. Funk $W$, Jakob $W$, Riedl $T$, Taeger $K$. Oral preanaesthetic medication for children: double-blind randomized study of a combination of midazolam and ketamine vs midazolam or ketamine alone. $\mathrm{Br} J$ Anaesth 2000;84:335-40.

98. Guit JB, Koning HM, Coster ML, et al. Ketamine as analgesic for total intravenous anaesthesia with propofol. Anaesthesia $1991 ; 46: 24-7$

99. Porter EJ, McQuay HI, Bullingham RE, et al. Comparison of effects of intraoperative and postoperative methadone: acute tolerance to the postoperative dose? $\mathrm{Br}$ J Anaesth 1983;55: 325-32. 
100. Satsumae T, Yamaguchi H, Sakaguchi M, et al. Preoperative small-dose ketamine prevented tourniquet-induced arterial pressure increase in orthopedic patients under general anesthesia. Anesth Analg 2001;92:1286-9.

101. Telci L, Esen F, Akcora D, et al. Evaluation of effects of magnesium sulphate in reducing intraoperative anaesthetic requirements. Br J Anaesth 2002;89:594-8.

102. Lee IO, Kim WK, Kong MH, et al. No enhancement of sensory and motor blockade by ketamine added to ropivacaine interscalene brachial plexus blockade. Acta Anaesthesiol Scand 2002;46:821-6.

103. Matot I, Oppenheim-Eden A, Ratrot R, et al. Preoperative cardiac events in elderly patients with hip fracture randomized to epidural or conventional analgesia. Anesthesiology 2003;98: 156-63.

104. Fernandez-Liesa JI, Panadero A. Use of intrathecal hyperbaric methadone in postoperative analgesia of thoracic surgery. Reg Anesth 2000;25:325.

105. Persson J, Axelsson G, Hallin RG, Gustafsson L. Beneficial effects of ketamine in a chronic pain state with allodynia possibly due to central sensitization. Pain 1995;60:217-22.

106. Guirimand F, Dupont X, Brasseur L, et al. The effects of ketamine on the temporal summation (wind-up) of the R(III) nociceptive flexion reflex and pain in humans. Anesth Analg $2000 ; 90: 408-14$

107. Lauretti GR, Gomes JM, Reis MP, Pereira NL. Low doses of epidural ketamine or neostigmine, but not midazolam, improve morphine analgesia in epidural terminal cancer pain therapy. J Clin Anesth 1999;11:663-8.

108. Nikolajsen L, Gottrup H, Kristensen AG, Jensen TS. Memantine (a $N$-methyl-D-aspartate receptor antagonist) in the treatment of neuropathic pain after amputation or surgery: a randomized, double-blinded, cross-over study. Anesth Analg 2000;91:960-6.

109. Yang CY, Wong CS, Chang JY, Ho ST. Intrathecal ketamine reduces morphine requirements in patients with terminal cancer pain. Can J Anaesth 1996;43:379-83.

110. Adam F, Libier M, Oszustowicz T, et al. Preoperative smalldose ketamine has no preemptive analgesic effect in patients undergoing total mastectomy. Anesth Analg 1999;89:444-7.

111. Holthusen $H$, Backhaus $P$, Boeminghaus $F$, et al. Preemptive analgesia: no relevant advantage of preoperative compared with postoperative intravenous administration of morphine, ketamine, and clonidine in patients undergoing transperitoneal tumor nephrectomy. Reg Anesth Pain Med 2002;27: $249-53$.

112. Aida S, Yamakura T, Baba $\mathrm{H}$, et al. Preemptive analgesia by intravenous low-dose ketamine and epidural morphine in gastrectomy: a randomized double-blind study. Anesthesiology 2000;92:1624-30.

113. Choe H, Choi YS, Kim YH, et al. Epidural morphine plus ketamine for upper abdominal surgery: improved analgesia from preincisional versus postincisional administration. Anesth Analg 1997;84:560-3.

114. Dahl V, Ernoe PE, Steen T, et al. Does ketamine have preemptive effects in women undergoing abdominal hysterectomy procedures? Anesth Analg 2000;90:1419-22.

115. Fu ES, Miguel R, Scharf JE. Preemptive ketamine decreases postoperative narcotic requirements in patients undergoing abdominal surgery. Anesth Analg 1997;84:1086-90.

116. Himmelseher S, Ziegler-Pithamitsis D, Argiriadou $\mathrm{H}$, et al. Small-dose $\mathrm{S}(+)$-ketamine reduces postoperative pain when applied with ropivacaine in epidural anesthesia for total knee arthroplasty. Anesth Analg 2001;92:1290-5.

117. Huang GS, Yeh CC, Kong SS, et al. Intra-articular ketamine for pain control following arthroscopic knee surgery. Acta Anaesthesiol Sin 2000;38:131-6.

118. Jaksch W, Lang S, Reichhalter R, et al. Perioperative small-dose $\mathrm{S}(+)$-ketamine has no incremental beneficial effects on postoperative pain when standard-practice opioid infusions are used. Anesth Analg 2002;94:981-6.
119. Kathirvel S, Sadhasivam S, Saxena A, et al. Effects of intrathecal ketamine added to bupivacaine for spinal anaesthesia. Anaesthesia 2000;55:899-904

120. Kirdemir P, Ozkocak I, Demir T, Gogus N. Comparison of postoperative analgesic effects of preemptively used epidural ketamine and neostigmine. J Clin Anesth 2000;12:543-8.

121. Lauretti GR, Azevedo VM. Intravenous ketamine or fentanyl prolongs postoperative analgesia after intrathecal neostigmine. Anesth Analg 1996;83:766-70.

122. Mathisen LC, Aasbo V, Raeder J. Lack of pre-emptive analgesic effect of (R)-ketamine in laparoscopic cholecystectomy. Acta Anaesthesiol Scand 1999;43:220-4.

123. Menigaux $C$, Fletcher D, Dupont $X$, et al. The benefits of intraoperative small-dose ketamine on postoperative pain after anterior cruciate ligament repair. Anesth Analg 2000;90: 129-35.

124. Menigaux C, Guignard B, Fletcher D, et al. Intraoperative small-dose ketamine enhances analgesia after outpatient knee arthroscopy. Anesth Analg 2001;93:606-12.

125. Mortero RF, Clark LD, Tolan MM, et al. The effects of smalldose ketamine on propofol sedation: respiration, postoperative mood, perception, cognition, and pain. Anesth Analg 2001;92: $1465-9$.

126. Papaziogas B, Argiriadou H, Papagiannopoulou $P$, et al. Preincisional intravenous low-dose ketamine and local infiltration with ropivacaine reduces postoperative pain after laparoscopic cholecystectomy. Surg Endosc 2001;15:1030-3.

127. Peat SJ, Bras P, Hanna MH. A double-blind comparison of epidural ketamine and diamorphine for postoperative analgesia. Anaesthesia 1989;44:555-8.

128. Roytblat L, Korotkoruchko A, Katz J, et al. Postoperative pain: the effect of low-dose ketamine in addition to general anesthesia. Anesth Analg 1993;77:1161-5.

129. Stubhaug A, Breivik H, Eide PK, et al. Mapping of punctuate hyperalgesia around a surgical incision demonstrates that ketamine is a powerful suppressor of central sensitization to pain following surgery. Acta Anaesthesiol Scand 1997;41:1124-32.

130. Subramaniam K, Subramaniam B, Pawar DK, Kumar L. Evaluation of the safety and efficacy of epidural ketamine combined with morphine for postoperative analgesia after major upper abdominal surgery. J Clin Anesth 2001;13:339-44.

131. Tanaka M, Sato M, Saito A, Nishikawa T. Reevaluation of rectal ketamine premedication in children: comparison with rectal midazolam. Anesthesiology 2000;93:1217-24.

132. Tverskoy $\mathrm{M}, \mathrm{Oz} Y$, Isakson $A$, et al. Preemptive effect of fentanyl and ketamine on postoperative pain and wound hyperalgesia. Anesth Analg 1994;78:205-9.

133. Tverskoy $M$, Oren $M$, Vaskovich $M$, et al. Ketamine enhances local anesthetic and analgesic effects of bupivacaine by peripheral mechanism: a study in postoperative patients. Neurosci Lett 1996;215:5-8.

134. Wong CS, Lu CC, Cherng $\mathrm{CH}$, Ho ST. Pre-emptive analgesia with ketamine, morphine and epidural lidocaine prior to total knee replacement. Can J Anaesth 1997;44:31-7.

135. Wilder-Smith OH, Arendt-Nielsen L, Gaumann D, et al. Sensory changes and pain after abdominal hysterectomy: a comparison of anesthetic supplementation with fentanyl versus magnesium or ketamine. Anesth Analg 1998;86:95-101.

136. Chia YY, Liu K, Chow LH, Lee TY. The preoperative administration of intravenous dextromethorphan reduces postoperative morphine consumption. Anesth Analg 1999;89:748-52.

137. Grace RF, Power I, Umedaly H, et al. Preoperative dextromethorphan reduces intraoperative but not postoperative morphine requirements after laparotomy. Anesth Analg 1998;87: 1135-8.

138. Helmy SA, Bali A. The effect of the preemptive use of the NMDA receptor antagonist dextromethorphan on postoperative analgesic requirements. Anesth Analg 2001;92:739-44.

139. Henderson DJ, Withington BS, Wilson JA, Morrison LM. Perioperative dextromethorphan reduces postoperative pain after hysterectomy. Anesth Analg 1999;89:399-402. 
140. Ilkjaer S, Bach LF, Nielsen PA, et al. Effect of preoperative oral dextromethorphan on immediate and late postoperative pain and hyperalgesia after total abdominal hysterectomy. Pain 2000;86:19-24.

141. McConaghy PM, McSorley P, McCaughey W, Campbell WI. Dextromethorphan and pain after total abdominal hysterectomy. Br J Anaesth 1998;81:731-6.

142. Rose JB, Cuy R, Cohen DE, Schreiner MS. Preoperative oral dextromethorphan does not reduce pain or analgesic consumption in children after adenotonsillectomy. Anesth Analg 1999;88:749-53.

143. Weinbroum AA, Lalayev G, Yashar T, et al. Combined preincisional oral dextromethorphan and epidural lidocaine for postoperative pain reduction and morphine sparing: a randomised double-blind study on day-surgery patients. Anaesthesia 2001;56:616-22.

144. Weinbroum AA. Dextromethorphan reduces immediate and late postoperative analgesic requirements and improves patients' subjective scorings after epidural lidocaine and general anesthesia. Anesth Analg 2002;94:1547-52.

145. Wu CT, Yu JC, Yeh CC, et al. Preincisional dextromethorphan treatment decreases postoperative pain and opioid requirement after laparoscopic cholecystectomy. Anesth Analg 1999; 88:1331-4.

146. Wu CT, Yu JC, Liu ST, et al. Preincisional dextromethorphan treatment for postoperative pain management after upper abdominal surgery. World J Surg 2000;24:512-7.

147. Kawamata T, Omote K, Kawamata M, Namiki A. Premedication with oral dextromethorphan reduces postoperative pain after tonsillectomy. Anesth Analg 1998;86:594-7.

148. Ko SH, Lim HR, Kim DC, et al. Magnesium sulfate does not reduce postoperative analgesic requirements. Anesthesiology 2001;95:640-6.

149. Tramer MR, Schneider J, Marti RA, Rifat K. Role of magnesium sulfate in postoperative analgesia. Anesthesiology 1996;84: $340-7$.
150. Zarauza R, Saez-Fernandez AN, Iribarren MJ, et al. A comparative study with oral nifedipine, intravenous nimodipine, and magnesium sulfate in postoperative analgesia. Anesth Analg $2000 ; 91: 938-43$.

151. Wilder-Smith $\mathrm{CH}$, Knopfli $\mathrm{R}$, Wilder-Smith $\mathrm{OH}$. Perioperative magnesium infusion and postoperative pain. Acta Anaesthesiol Scand 1997;41:1023-7.

152. Moiniche S, Mikkelsen S, Wetterslev J, Dahl JB. A qualitative systematic review of incisional local anaesthesia for postoperative pain relief after abdominal operations. $\mathrm{Br} J$ Anaesth 1998; 81:377-83.

153. Ilkjaer S, Bach LF, Nielsen PA, et al. Effect of preoperative oral dextromethorphan on immediate and late postoperative pain and hyperalgesia after total abdominal hysterectony. Pain 2000;86:19-24.

154. Kissin I. Preemptive analgesia: why its effect is not always obvious. Anesthesiology 1996;84:1015-9.

155. Moher D, Pham B, Klassen TP, et al. What contributions do languages other than English make on the results of metaanalyses? J Clin Epidemiol 2000;53:964-72.

156. Cairns BE, Gambarota G, Svensson P, et al. Glutamate-induced sensitization of rat masseter muscle fibers. Neuroscience 2002; 109:389-99.

157. Cairns BE, Svensson P, Wang K, et al. Activation of peripheral NMDA receptors contributes to human pain and rat afferent discharges evoked by injection of glutamate into the masseter muscle. J Neurophysiol 2003;90:2098-105.

158. Svensson P, Cairns BE, Wang K, et al. Glutamate-evoked pain and mechanical allodynia in the human masseter muscle. Pain 2003;101:221-7.

159. Kissin I, Bright CA, Bradley EL Jr. The effect of ketamine on opioid-induced acute tolerance: can it explain reduction of opioid consumption with ketamine-opioid analgesic combinations? Anesth Analg 2000;91:1483-8. 